\title{
Front Matter: Volume 7412
}

, "Front Matter: Volume 7412," Proc. SPIE 7412, Reliability of Photovoltaic Cells, Modules, Components, and Systems II, 741201 (14 September 2009); doi: $10.1117 / 12.844892$

SPIE Event: SPIE Solar Energy + Technology, 2009, San Diego, California, United SPIE. States 


\section{PROCEEDINGS OF SPIE}

\section{Reliability of Photovoltaic Cells, Modules, Components, and Systems II}

Neelkanth G. Dhere

John H. Wohlgemuth

Dan T. Ton

Editors

3-6 August 2009

San Diego, California, United States

Sponsored and Published by

SPIE

Volume 7412 
The papers included in this volume were part of the technical conference cited on the cover and title page. Papers were selected and subject to review by the editors and conference program committee. Some conference presentations may not be available for publication. The papers published in these proceedings reflect the work and thoughts of the authors and are published herein as submitted. The publisher is not responsible for the validity of the information or for any outcomes resulting from reliance thereon.

Please use the following format to cite material from this book:

Author(s), "Title of Paper," in Reliability of Photovoltaic Cells, Modules, Components, and Systems II, edited by Neelkanth G. Dhere, John H. Wohlgemuth, Dan T. Ton, Proceedings of SPIE Vol. 7412 (SPIE, Bellingham, WA, 2009) Article CID Number.

ISSN 0277-786X

ISBN 9780819477026

Published by

SPIE

P.O. Box 10, Bellingham, Washington 98227-0010 USA

Telephone +1 3606763290 (Pacific Time) · Fax +1 3606471445

SPIE.org

Copyright (C) 2009, Society of Photo-Optical Instrumentation Engineers

Copying of material in this book for internal or personal use, or for the internal or personal use of specific clients, beyond the fair use provisions granted by the U.S. Copyright Law is authorized by SPIE subject to payment of copying fees. The Transactional Reporting Service base fee for this volume is $\$ 18.00$ per article (or portion thereof), which should be paid directly to the Copyright Clearance Center (CCC), 222 Rosewood Drive, Danvers, MA 01923. Payment may also be made electronically through CCC Online at copyright.com. Other copying for republication, resale, advertising or promotion, or any form of systematic or multiple reproduction of any material in this book is prohibited except with permission in writing from the publisher. The CCC fee code is 0277-786X/09/ $\$ 18.00$.

Printed in the United States of America.

Publication of record for individual papers is online in the SPIE Digital Library.

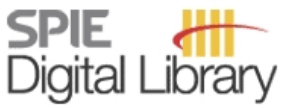

SPIEDigitalLibrary.org

Paper Numbering: Proceedings of SPIE follow an e-First publication model, with papers published first online and then in print and on CD-ROM. Papers are published as they are submitted and meet publication criteria. A unique, consistent, permanent citation identifier (CID) number is assigned to each article at the time of the first publication. Utilization of CIDs allows articles to be fully citable as soon they are published online, and connects the same identifier to all online, print, and electronic versions of the publication. SPIE uses a six-digit CID article numbering system in which:

- The first four digits correspond to the SPIE volume number.

- The last two digits indicate publication order within the volume using a Base 36 numbering system employing both numerals and letters. These two-number sets start with 00, 01, 02, 03, 04, $05,06,07,08,09,0 A, 0 B \ldots 0 Z$, followed by 10-1Z, 20-2Z, etc.

The CID number appears on each page of the manuscript. The complete citation is used on the first page, and an abbreviated version on subsequent pages. Numbers in the index correspond to the last two digits of the six-digit CID number. 


\section{Contents}

vii Conference Committee

ix Introduction

xi Concentrating solar energy for utility scale applications (Plenary Paper) [7407-106]

R. Sherif, esolar, Inc. (United States)

xvii Recent progress in photocatalysts for overall water splitting under visible light (Plenary Paper) [7408-103]

T. Hisatomi, K. Domen, The Univ. of Tokyo (Japan)

\section{METROLOGY AND CERTIFICATION}

741202 Development and application of a UV light source for PV-module testing (Invited Paper) [7412-01]

M. Koehl, D. Philipp, Fraunhofer Institute for Solar Energy Systems (Germany); N. Lenck, SCHOTT Solar GmbH (Germany); M. Zundel, SLZ Maschinenbau GmbH (Germany)

741203 Measurement and simulation of dynamic mechanical loads on PV-modules [7412-02] K.-A. Weiss, M. Assmus, S. Jack, M. Koehl, Fraunhofer Institute for Solar Energy Systems (Germany)

741204 Striving for a standard protocol for preconditioning or stabilization of polycrystalline thin film photovoltaic modules [7412-03]

J. A. del Cueto, C. A. Deline, D. S. Albin, S. R. Rummel, A. Anderberg, National Renewable Energy Lab. (United States)

\section{RELIABILITY OF CONCENTRATOR CELLS AND OPTICS: JOINT SESSION WITH CONFERENCE} 7407

741206 Stress in large-area optics for solar concentrators (Invited Paper) [7412-05]

R. Leutz, L. Fu, H. P. Annen, Concentrator Optics GmbH (Germany)

741208 Assuring long-term reliability of concentrator PV systems [7412-08]

R. McConnell, V. Garboushian, J. Brown, C. Crawford, K. Darban, D. Dutra, S. Geer,

V. Ghassemian, R. Gordon, G. Kinsey, K. Stone, G. Turner, Amonix, Inc. (United States)

ENCAPSULANT/BACKSHEETS

741209 Influence of glass morphology and internal topography on moisture penetration for glass/PVB/glass laminates (Invited Paper) [7412-09]

S. Krull, I. Sinicco, Oerlikon Solar (Switzerland) 
7412 0A Impact of moisture on PV module encapsulants [7412-10]

T. Swonke, R. Aver, Bavarian Ctr. of Applied Energy Research (Germany)

$7412 \mathrm{OB} \quad$ A semi-empirical method of predicting the lifetime of EVA encapsulant and polyester based backsheet materials (Invited Paper) [7412-11]

Z. Xia, J. H. Wohlgemuth, D. W. Cunningham, BP Solar International Inc. (United States)

7412 OC Research on the non-thermal DBD surface modification and the humidity-heat aging resistant performance in solar cell modules of FFC backsheet [7412-12]

Q. Si, Z. Fei, J. Jin, Jolywood (Suzhou) Solar Material Technology Co., Ltd. (China); H. Qiu, Hangzhou Normal Univ. (China); Y. Zhang, Jolywood (Suzhou) Solar Material Technology Co., Ltd. (China)

\section{RELIABILITY OF BOS COMPONENTS AND PV SYSTEMS}

7412 OE Temperature of rooftop photovoltaic modules: air gap effects (Invited Paper) [7412-14] B. L. Shrestha, Arizona State Univ. (United States); E. G. Palomino, Salt River Project (United States); G. TamizhMani, Arizona State Univ. (United States) and TÜV Rheinland PTL (United States)

7412 OF 2008 performance analysis of a large scale grid connected solar system [7412-15] A. Alami, R. Batista, D. Williams, Renewable Ventures, a Fotowatio Co. (United States)

$74120 \mathrm{U}$ Using probabilistic methods to define reliability requirements for high power inverters [7412-16]

R. W. Morris, The Boeing Co. (United States); J. M. Fife, PV Powered, Inc. (United States)

$7412 \mathrm{OH} \quad$ Study on the heat dissipation performance of different types of junction boxes [7412-17] F. Kong, J. Zhao, J. Cai, Phono Solar Technology Co., Ltd. (China)

\section{THIN FILM PV RELIABILITY}

7412 Ol Degradation and capacitance: voltage hysteresis in CdTe devices (Invited Paper) [7412-18] D. S. Albin, R. G. Dhere, S. C. Glynn, J. A. del Cueto, W. K. Metzger, National Renewable Energy Lab. (United States)

$74120 \mathrm{~J} \quad$ Stability of TCO window layers for thin-film CIGS solar cells upon damp heat exposures: part II [7412-19] R. Sundaramoorthy, F. J. Pern, C. DeHart, T. Gennett, National Renewable Energy Lab. (United States); F. Y. Meng, Shanghai Jiao Tong Univ. (China); M. Contreras, T. Gessert, National Renewable Energy Lab. (United States)

7412 OK Stability of TCO window layers for thin-film CIGS solar cells upon damp heat exposures: part III (Invited Paper) [7412-20]

F. J. Pern, S. H. Glick, X. Li, C. DeHart, T. Gennett, M. Contreras, T. Gessert, National Renewable Energy Lab. (United States)

$7412 \mathrm{OL} \quad$ Understanding and mitigating effects of nonuniformities on reliability of thin film photovoltaics (Invited Paper) [7412-21]

V. G. Karpov, D. Shvydka, Univ. of Toledo (United States) 
$74120 \mathrm{M}$ Mechanical scribing as a quality and reliability analysis tool for CIGSeS thin film solar cells [7412-22]

S. A. Pethe, M. J. Mendoza, A. Kaul, N. G. Dhere, Univ. of Central Florida (United States)

\section{LONG TERM PV MODULE RELIABILITY}

7412 ON Product reliability and thin-film photovoltaics (Invited Paper) [7412-23]

R. Gaston, R. Feist, S. Yeung, M. Hus, M. Bernius, M. Langlois, S. Bury, The Dow Chemical Co. (United States); J. Granata, M. Quintana, Sandia National Labs. (United States); C. Carlson, G. Sarakakis, D. Ogden, A. Mettas, ReliaSoft Corp. (United States)

7412 OP Failure analysis methods applied to PV module reliability (Invited Paper) [7412-25] W. J. Gambogi, E. F. McCord, H. D. Rosenfeld, R. H. Senigo, S. Peacock, K. M. Stika, E.I. DuPont de Nemours \& Co., Inc. (United States)

$74120 Q \quad$ Effects of cerium removal from glass on photovoltaic module performance and stability (Invited Paper) [7412-26]

M. D. Kempe, T. Moricone, National Renewable Energy Lab. (United States); M. Kilkenny, Skyline Solar (United States)

7412 OR Accelerated testing of metal foil tape joints and their effect of photovoltaic module reliability [7412-27]

N. R. Sorensen, M. A. Quintana, J. D. Puskar, S. J. Lucero, Sandia National Labs. (United States)

7412 OS Outdoor monitoring and high voltage bias testing of PV modules as necessary test for assuring long term reliability [7412-28]

N. G. Dhere, S. A. Pethe, A. Kaul, Univ. of Central Florida (United States)

\section{POSTER SESSION}

7412 OU Diagnostic methods of solar cells in dependence on temperature [7412-30]

J. Dolensky, A. Vesely, J. Vanek, J. Hrozek, Brno Univ. of Technology (Czech Republic)

7412 0X Pyretic test and breakdown test for C-Si PV cells and single-cell PV modules [7412-34]

T. Doi, T. Yamada, K. Ikeda, National Institute of Advanced Industrial Science and Technology (Japan)

7412 OY Effects of module performance and long-term degradation on economics and energy payback: case study of two different photovoltaic technologies [7412-35]

K. Davis, H. Moaveni, Univ. of Central Florida (United States)

\section{SOLAR ENERGY PLENARY SESSION}

$74120 Z$ Photovoltaic-reliability R\&D toward a solar-powered world (Plenary Paper) [7412-104] S. Kurtz, National Renewable Energy Lab. (United States); J. Granata, M. Quintana, Sandia National Labs. (United States)

Author Index 
Downloaded From: https://www.spiedigitallibrary.org/conference-proceedings-of-spie on 26 Apr 2023

Terms of Use: https://www.spiedigitallibrary.org/terms-of-use 


\title{
Conference Committee
}

\author{
Symposium Chair
}

Martha Symko-Davies, National Renewable Energy Laboratory (United States)

Conference Chair

Neelkanth G. Dhere, University of Central Florida (United States)

Conference Cochairs

John H. Wohlgemuth, BP Solar International Inc. (United States)

Dan T. Ton, U.S. Department of Energy (United States)

Program Committee

David S. Albin, National Renewable Energy Laboratory (United States)

Ward Bower, Sandia National Laboratories (United States)

Michael DeBergalis, DuPont Company (United States)

Alan E. Delahoy, EPV Solar, Inc. (United States)

Jennifer E. Granata, Sandia National Laboratories (United States)

Steve Hogan, Spire Corporation (United States)

Michael Köhl, Fraunhofer-Institut für Solare Energiesysteme (Germany)

Ralf Leutz, Philipps-Universität Marburg (Germany) and Concentrator Optics GmbH (Germany)

Xavier Mathew, Universidad Nacional Autónoma de México (Mexico)

Robert McConnell, Amonix Inc. (United States)

John Pern, National Renewable Energy Laboratory (United States)

Bolko von Roedern, National Renewable Energy Laboratory (United States)

Charles Whitaker, BEW Engineering, Inc. (United States)

Session Chairs

1 Metrology and Certification

John H. Wohlgemuth, BP Solar International Inc. (United States)

2 Reliability of Concentrator Cells and Optics: Joint Session with Conference 7407

Dan T. Ton, U.S. Department of Energy (United States)

3 Encapsulant/Backsheets

John Pern, National Renewable Energy Laboratory (United States) 
$4 \quad$ Stability and Degradation Processes in Organic Solar Cells: Joint Session with Conference 7416

Steve Hogan, Spire Corporation (United States)

$5 \quad$ Reliability of BOS Components and PV Systems

Kristopher O. Davis, University of Central Florida (United States)

$6 \quad$ Thin Film PV Reliability

Jennifer E. Granata, Sandia National Laboratories (United States)

$7 \quad$ Long Term PV Module Reliability

David S. Albin, National Renewable Energy Laboratory (United States)

Solar Energy Plenary Session

Martha Symko-Davies, National Renewable Energy Laboratory (United States) 


\section{Introduction}

Development of a sustainable renewable energy source is the need of the day and photovoltaic (PV) technology has a very important role to play in this effort. With the increasing concern over high carbon emission and the effects of global warming and the high fuel prices, the need for establishing PV as the alternative source of energy has become of paramount importance. For any technology to sustain, it is absolutely essential that the product be reliable and that it operates properly over its useful lifetime.

The Reliability of PV Modules session of the SPIE 2008 Optics and Photonics event was the first step in achieving the reliability and long term durability of PV modules. This effort was taken further during the SPIE 2009 Optics and Photonics event where a platform was provided, through a two day session on reliability of PV modules, for PV researchers from various companies, national laboratories, and universities to discuss their research.

Twenty-nine papers were presented and twenty-seven papers were published for this conference. The conference was divided into one plenary session, seven oral sessions, and one poster session extending over a four-day period from 3-6 August 2009. Session one, titled Metrology and Certification, had interesting presentations discussing development of UV light sources, the effect and accurate measurement of mechanical loads such as wind loads and establishing a standard protocol for preconditioning and stabilizing thin film PV modules prior to testing.

One of the talks during the plenary session by Sarah Kurtz, titled PhotovoltaicReliability R\&D toward a Solar-Powered World, discussed the importance of reliability as well as the necessity to study the reliability aspect of PV modules in order to develop PV technology as one of the major source of energy in the world.

With higher efficiencies achieved by III-V single junction and multi-junction cells, the topic of session two, Reliability of Concentrator Cells and Optics, was garnering a lot of interest. This session was a joint session with conference 7407: High and Low Concentrator Systems for Solar Electric Applications IV. Research work on the reliability of the concentrator optics and cells as well as various testing techniques and models was discussed during this session.

A good packaging scheme means an improved reliability of PV modules. Encapsulants and backsheets are two of the widely researched materials of the packaging scheme. Session three discussed various encapsulant and backsheet materials as well as various techniques to determine the lifetime of these materials. 
Session four, titled Stability and Degradation Processes in Organic Solar Cells, was held as a joint session with conference 7416: Organic Photovoltaics X. Another aspect that needs attention towards establishing PV as a sustainable alternative source of energy is the reliability of the balance of system (BOS) components.

Session five, titled Reliability of BOS Components and PV Systems, had presentations discussing BOS components such as inverters, junction boxes, as well as PV systems as a whole.

The market share of thin film PV is increasing by the day; however, there is not enough understanding of some the key issues involved with reliability of thin film PV modules. The degradation mechanisms in thin film PV modules are different from that in C-Si PV and need to be understood to improve the processing techniques and eventually the reliability of PV modules. Session six discussed various issues involved in reliability of thin film PV modules.

Accelerated testing tackles the issues of infant mortality of PV modules; however, there is a need to carry out field testing of various PV technology modules in order to determine the useful lifetime and to estimate the degradation rates for various technologies. Session seven had several presentations discussing various methods to carry out long term reliability testing of PV modules and the need for a combined, sustained, and symbiotic effort among various universities and PV manufacturers to develop a program that allows the growth of the PV community as a whole.

As part of this conference a short course on design and reliability of photovoltaic modules was offered. The course was well attended and appreciated by the attendees. The focus of the tutorial was on various packaging configurations, application of concepts of physics of failure to PV systems with several examples, development of accelerated tests for various technologies, and the application of this knowledge in development of new products and technologies such as organic PV.

\section{Neelkanth G. Dhere John H. Wohlgemuth Dan T. Ton}

